\title{
ANALISIS EKSISTENSI SEKTOR DAN KOMODITI UNGGULAN DALAM MEMPERCEPAT PENANGGULANGAN KEMISKINAN DI KABUPATEN MINAHASA UTARA
}

\author{
Amran Naukoko, Vekie A. Rumate, Een N Walewangko \\ ${ }^{123}$ Jurusan Ekonomi Pembangunan, Fakultas Ekonomi dan Bisnis, \\ Universitas Sam Ratulangi, Manado 95115, Indonesia \\ Email : atnaukoko@gmail.com
}

\begin{abstract}
ABSTRAK
Pembangunan ekonomi daerah merupakan suatu proses rangkaian kegiatan yang dilakukan oleh pemerintah daerah dan juga masyarakat secara besama-sama dalam mengelola dan memanfaatkan potensi sumber daya yang tesedia secara optimal serta membentuk suatu pola kemitraan antara pemerintah daerah dengan sektor swasta untuk menciptakan suatu lapangan kerja baru dalam merangsang perkembangan kegiatan ekonomi di daerah. Kabupaten Minahasa Utara merupakan salah satu daerah yang ada di wilayah Propinsi Sulawesi Utara yang memiliki potensi Sumber Daya Alam (SDA) serta keunggulan komparatif dan kompetitif yang kuat sebagai lokasi aktivitas ekonomi. Penelitian ini bertujuan untuk mengidentifikasi sektor dan komoditi apa yang unggul serta potensial yang ada di Kabupaten Minahasa Utara, dan menganalisis sektor dan komoditi unggulan apa yang mempercepat penanggulangan kemiskinan di Kabupaten Minahasa Utara.

Data yang digunakan adalah data sekunder yang di ambil dari Badan Pusat Statistik Provinsi Sulawesi Utara Tahun 2010-2015 dan data primer yang diperoleh langsung dari pelakupelaku usaha Industri Kecil dan Mikro yang ada di Kabupaten Minahasa Utara. Metode yang di gunakan adalah LQ (Location Quotient) dan Shift Share untuk mengidentifikasi sektor dan komoditi unggulan. Metode Analisis Regresi Berganda untuk melihat pengaruh dari UMKM sector unggulan terhadap percepatan penanggulangan kemiskinan di Kabupaten Minahasa Utara. Hasil penelitian Sektor Basis di kabupaten Minahasa Utara adalah Sektor pertanian, kehutanan dan perikanan; Sektor pertambangan dan penggalian; Sektor industri pengolahan; Sektor pengadaan listrik dan gas; Sektor konstruksi; Sektor Real Estate dan Sektor Jasa Pendidikan. Pertumbuhan ekonomi di Provinsi Sulawesi Utara memberikan pengaruh positif terhadap perekonomian di Kabupaten Minahasa Utara. Perekonomian Kabupaten Minahasa Utara mengalami kemajuan dan mulai memiliki daya saing. Sektor yang memberi pengaruh terbesar dalam percepatan penanggulangan kemiskinan di Kabupaten Minahasa Utara adalah sector industry pengolahan diikuti sector pertanian dan sektor konstruksi.
\end{abstract}

\section{Kata Kunci : Sektor Unggulan, UMKM dan Kemiskinan}




\section{PENDAHULUAN}

\section{Latar Belakang}

Pembangunan ekonomi daerah merupakan suatu proses rangkaian kegiatan yang dilakukan oleh pemerintah daerah dan juga masyarakat secara besama-sama dalam mengelola dan memanfaatkan potensi sumber daya yang tesedia secara optimal serta membentuk suatu pola kemitraan antara pemerintah daerah dengan sektor swasta untuk menciptakan suatu lapangan kerja baru dalam merangsang perkembangan kegiatan ekonomi di daerah. Aspek pertumbuhan ekonomi daerah menjadi salah satu indikator penilaian keberhasilan pelaksanaan pembangunan ekonomi di suatu wilayah yang diukur dari besaran nilai tambah bruto (gross value added) yang timbul dari seluruh sektor perekonomian di suatu wilayah dalam jangka waktu tertentu atau disebut dengan Produk Domestik Regional Bruto (PDRB). Pendorong pertumbuhan ekonomi sektoral membutuhkan informasi tentang sector basis dan non basis yang menopang perekonomian.

Pembangunan ekonomi daerah yang diharapkan oleh UU No.32 Tahun 2004 adalah pembangunan ekonomi yang dicapai dengan cara memanfaatkan potensi daerah secara optimal dengan kebijakan dan kewenangan yang dimiliki oleh pemerintah daerah. Kesiapan daerah dalam menjalankan otonomi daerah haruslah didukung oleh potensi, Sumber Daya Alam (SDA) serta kemampuan masyarakat dan kewenangan pemerintah daerah dalam mengelolah sumber daya yang ada secara optimal. Pemerintah daerah di harapkan mampu melihat sektor yang memiliki keunggulan/kelemahan di wilayahnya sehingga dapat menetukan kebijakan pembangunan ekonomi daerah. Ini menjadi salah satu cara percepatan pencapaian visi dan misi pemerintah daerah.

Untuk memacu laju pertumbuhan ekonomi regional dan meningkatkan kontribusinya terhadap pembentukan total Produk Domestik Regional Bruto (PDRB), maka pembangunan sektor unggulan dapat dijadikan sebagai penggerak pembangunan ekonomi. Secara umum tujuan pembangunan bidang ekonomi khususnya sektor unggulan adalah untuk mempercepat laju pertumbuhan ekonomi dengan demikian dapat tercipta stabilitas ekonomi yang sehat dan dinamis, dan tercipta kemakmuran dan kesejahteraan yang dinikmati oleh masyarakat daerah tersebut.

Menurut Fachrurrozy (2009) pembangunan daerah dengan pendekatan sektoral mengkaji berdasarkan kegiatan usaha yang dikelompokkan menurut jenisnya ke dalam sektor dan sub sektor. Pemerintah daerah harus mengetahui dan dapat menentukan penyebab tingkat pertumbuhan dan stabilitas dari perekonomian wilayahnya.

Identifikasi sektor dan sub sektor yang dapat menunjukkan keunggulan komparatif daerah merupakan tugas utama pemerintah daerah. Dengan mengetahui sektor unggulan apa yang terdapat di daerah mampu memberikan indikasi perekonomian secara nasional dan regional. Potensi yang di miliki sektor unggulan akan mampu memberikan pertumbuhan lebih cepat dibandingkan dengan sektor lainnya yang ada di daerah tersebut.

Menurut Rachbini (2001) ada empat syarat agar suatu sektor tertentu menjadi sektor prioritas, yakni (1) sektor tersebut harus menghasilkan produk yang mempunyai permintaan yang cukup besar, sehingga laju pertumbuhan berkembang cepat akibat dari efek permintaan tersebut; (2) karena ada perubahan teknologi yang teradopsi secara kreatif, maka fungsi produksi baru bergeser dengan pengembangan kapasitas yang lebih luas; (3) harus terjadi peningkatan investasi kembali dari hasil-hasil produksi sektor yang menjadi prioritas tersebut, baik swasta maupun pemerintah; (4) sektor tersebut harus berkembang, sehingga mampu memberi pengaruh terhadap sektor-sektor lainnya. 
Kabupaten Minahasa Utara merupakan salah satu daerah yang ada di wilayah Propinsi Sulawesi Utara yang memiliki potensi Sumber Daya Alam (SDA) serta keunggulan komparatif dan kompetitif yang kuat sebagai lokasi aktivitas ekonomi. Kabupaten Minahasa Utara memiliki peran penting dalam mendorong peningkatan peranan berbagai pelaku ekonomi. Letaknya yang strategis karena berada di pinggir wilayah Pasifik, menjadikannya jalur perdagangan dunia di masa depan, khususnya dengan negara di kawasan Asia Pasifik seperti Jepang, China, Korea, hingga Benua Amerika. Kekuatan geografis ini menjadikan Kabupaten Minahasa Utara layak sebagai wilayah utama pengembangan koridor ekonomi Indonesia. Salah satu tolak ukur keberhasilan pembangunan ekonomi di Kabupaten Minahasa Utara dilihat dari pertumbuhan ekonomi (PDRB).

Visi Kabupaten Minahasa Utara 2016-2021 adalah Minahasa Utara menjadi Kabupaten Agribisnis, Industri dan Pariwisata Secara Terpadu serta Keberlanjutan di Tahun 2021. Untuk mencapai visi ini telah ditetapkan 7 (tujuh) misi pembangunan yaitu :

1. Mengembangkan agribisnis secara efisien dan efektif.

2. Mewujudkan kawasan industry yang berwawasan lingkungan mendukung KEK di Kauditan, Kema dan Likupang Raya.

3. Meningkatkan daya tarik pariwisata.

4. Meningkatkan kualitas SDM.

5. Menyediakan infrastruktur yang memadai.

6. Menciptakan birokrasi pemerintahan yang baik, bersih dan melayani.

7. Mempersiapkan Kabupaten yang berdaya saing menghadapi MEA dan menuju Indonesia sebagai poros maritim dunia.

Tabel 1 Produk Domestik Regional Bruto Kabupaten Minahasa Utara Tahun 2010-2015 (jutaan rupiah)

\begin{tabular}{|c|c|c|c|c|c|c|}
\hline \multirow{2}{*}{ Lapangan Usaha } & \multicolumn{6}{|c|}{ Tahun } \\
\hline & 2010 & 2011 & 2012 & 2013 & 2014 & 2015 \\
\hline $\begin{array}{l}\text { Pertanian, Kehutanan, dan } \\
\text { Perikanan }\end{array}$ & $1,606,113.4$ & $1,639,266.8$ & $1,757,227.9$ & $1,860,480.4$ & $1,969,057.4$ & $2,032,528.2$ \\
\hline Pertambangan dan Penggalian & $514,338.0$ & $559,597.7$ & $601,701.1$ & $651,057.5$ & $699,281.3$ & $767,257.6$ \\
\hline Industri Pengolahan & $720,249.0$ & $777,838.8$ & $836,500.7$ & $886,961.3$ & $931,753.1$ & $983,050.0$ \\
\hline Pengadaan Listrik dan Gas & $5,244.9$ & $5,594.4$ & $6,244.4$ & $7,218.1$ & $7,958.9$ & $8,541.3$ \\
\hline $\begin{array}{l}\text { Pengadaan Air, Pengelolaan } \\
\text { Sampah, Limbah \& Daur Ulang }\end{array}$ & $4,446.4$ & $4,722.6$ & $5,057.3$ & $5,436.8$ & $5,609.9$ & $5,779.5$ \\
\hline Konstruksi & $660,094.1$ & $726,491.1$ & $786,179.2$ & $845,631.2$ & $932,626.6$ & $1,043,345.0$ \\
\hline $\begin{array}{l}\text { Perdagangan Besar dan Eceran; } \\
\text { Reparasi Mobil dan Sepeda Motor }\end{array}$ & 475,913 . & 523,123 & 537,798 & $584,956.2$ & $644,824.3$ & $692,559.0$ \\
\hline Transportasi dan Pergudangan & $209,790.2$ & $226,366.3$ & $244,457.6$ & $260,953.3$ & $284,610.9$ & $308,065.7$ \\
\hline $\begin{array}{l}\text { Penyediaan Akomodasi dan Makan } \\
\text { Minum }\end{array}$ & $49,676.9$ & $53,709.8$ & $57,329.4$ & $63,066.4$ & $69,237.0$ & $75,422.2$ \\
\hline Informasi dan Komunikasi & $100,452.4$ & $105,289.3$ & $112,798.5$ & $123,191.3$ & $135,813.9$ & $149,153.0$ \\
\hline Jasa Keuangan dan Asuransi & $41,354.6$ & $44,912.9$ & $49,212.6$ & $50,959.3$ & $53,026.5$ & $55,147.4$ \\
\hline Real Estate & $272,211.0$ & $298,747.1$ & $321,703.4$ & $344,650.4$ & $379,356.2$ & $417,003.8$ \\
\hline Jasa Perusahaan & 792.2 & 866.6 & 929.7 & 993.2 & $1,081.9$ & $1,172.5$ \\
\hline $\begin{array}{l}\text { Administrasi Pemerintahan, } \\
\text { Pertahanan dan Jaminan Sosial } \\
\text { Wajib }\end{array}$ & $193,849.8$ & $211,266.7$ & $230,966.5$ & $246,633.3$ & $270,415.7$ & $293,466.4$ \\
\hline Jasa Pendidikan & $143,766.3$ & $156,484.5$ & $167,725.2$ & $179,222.5$ & $188,347.9$ & $204,649.2$ \\
\hline $\begin{array}{l}\text { Jasa Kesehatan dan Kegiatan } \\
\text { Sosial }\end{array}$ & $135,042.4$ & $148,234.3$ & $157,103.7$ & $167,138.5$ & $176,872.1$ & $190,923.4$ \\
\hline Jasa lainnya & $31,233.0$ & $34,484.1$ & $36,956.8$ & $39,521.2$ & $41,594.9$ & $44,840.0$ \\
\hline
\end{tabular}


Sumber Data : BPS Sulut

Pada Tabel 1 memperlihatkan bahwa perkembangan PDRB Kabupaten Minahasa Utara selama tahun 2010 sampai 2015 terus mengalami peningkatan setiap tahunnya dengan rata-rata sebesar 6.162.316,83 juta rupiah. Kondisi ini tidak lepas dari peranan berbagai sektor ekonomi yang ada di Kabupaten Minahasa Utara. Dari tujuh belas sektor ekonomi, sektor pertanian, kehutanan dan perikanan memberikan kontribusi terbesar bagi PDRB Kabupaten Minahasa Utara dengan rata-rata sebesar $1.810 .779,02$ juta rupiah per tahunnya. Sedangkan kontribusi terendah di berikan oleh sektor pengadaan air, pengelolaan sampah, limbah dan daur ulang dengan rata-rata sebesar 5.175,42 juta rupiah setiap tahunnya. Pengembangan ekonomi daerah yang di fokuskan pada pengembangan sektor- sektor ekonomi unggulan dan potensial serta pengembangan Komoditi yang terkonsentrasi di masing-masing kecamatan di Kabupaten Minahasa Utara dapat membantu proses pembangunan berjalan lebih efektif dan efisien. Mengingat sejak otonomi daerah dicanangkan, setiap pemerintah daerah diberi kewenangan yang luas dalam menggali dan mengoptimalkan potensi sumber-sumber ekonomi yang terdapat di wilayahnya sebagai sumber Pendapatan Asli Daerah (PAD) guna membiayai kebutuhan pembiayaan pembagunan daerah dalam rangka peningkatan pelayanan publik sekaligus pertumbuhan ekonomi daerah.

Dengan demikian identifikasi sektor-sektor ekonomi unggulan menjadi salah satu bagian penting yang harus dilakukan dalam perencanaan pembangunan ekonomi daerah dalam rangka peningkatan pertumbuhan ekonomi daerah. Pembangunan ekonomi di Kabupaten Minahasa Utara merupakan salah satu prioritas Pemerintah Kabupaten Minahasa Utara sebagai upaya untuk meningkatkan pertumbuhan ekonomi daerah, kesempatan kerja bagi masyarakat dan daya saing wilayah.

Secara umum, penelitian ini bertujuan untuk mengidentifikasi sektor/ industri/bidang usaha yang potensial di Kabupaten Minahasa Utara, dengan mengevaluasi keunggulan komparatif yang tersedia di wilayah tersebut.

\section{Rumusan Masalah}

- Sektor dan Komoditi manakah yang unggul dan potensial di Kabupaten Minahasa Utara?

- Sektor dan Komoditi unggulan apa yang mempercepat penanggulangan kemiskinan di Kabupaten Minahasa Utara?

\section{Tinjaun Pustaka}

\section{Pembangunan Ekonomi}

Pembangunan ekonomi adalah upaya untuk meningkatkan laju pertumbuhan pendapatan per kapita suatu negara secara berkelanjutan agar dapat meningkatkan output (produk domestik bruto) dengan laju yang lebih tinggi dibandingkan dengan laju pertumbuhan penduduknya. Artinya, perlunya rencana mengubah struktur produksi dan lapangan kerja untuk menurunkan kontribusi sektor pertanian dan meningkatkan kontribusi sektor industri serta sektor jasa. Oleh karena itu, fokus pembangunan ekonomi di masa lalu adalah mempercepat proses industrialisasi, mengabaikan sektor pertanian dan pembangunan di wilayah pedesaan. (Todaro dan Smith, 2011).

\section{Teori Basis Ekonomi}

Inti dari teori basis ekonomi adalah bahwa permintaan terhadap input hanya dapat meningkat melalui peningkatan permintaan terhadap output yang dihasilkan oleh sektor basis (ekspor) dan sektor non-basis (lokal dan jasa-jasa). Permintaan terhadap produksi sektor lokal 
hanya akan meningkat apabila pendapatan masyarakat lokal juga meningkat. Namun demikian, peningkatan pendapatan tersebut hanya terjadi apabila sektor basis (ekspor) meningkat, khususnya yang menggunakan sumberdaya lokal. Oleh karena itu, ekspor wilayah merupakan faktor penentu dalam pengembangan wilayah karena akan meningkatkan kesejahteraan masyarakat dan meningkatkan kesempatan kerja di wilayah tersebut (Rustiadi et al.,2011 dan Blakely dan Bradshaw, 2002).

\section{Komoditas Unggulan}

Komoditas unggulan adalah komoditas andalan yang memiliki posisi strategis untuk dikembangkan di suatu wilayah berdasarkan pada pertimbangan teknis (kondisi tanah dan iklim), sosial ekonomi dan kelembagaan. Penentuan komoditas unggulan di suatu wilayah merupakan hal yang sangat penting karena ketersediaan dan kemampuan sumber daya alam, modal, dan sumberdaya manusia untuk memproduksi dan memasarkan semua komoditas yang dapat dihasilkan di suatu wilayah secara simultan relatif terbatas.

Penentuan komoditas unggulan merupakan langkah awal menuju pembangunan pertanian yang berpijak pada konsep efisiensi untuk meraih keunggulan komparatif dan kompetitif dalam menghadapi globalisasi perdagangan. Langkah menuju efisiensi dapat ditempuh dengan mengembangkan komoditas yang memiliki keunggulan komparatif, baik ditinjau dari sisi penawaran maupun permintaan. Dari sisi penawaran komoditas unggulan dicirikan oleh superioritas dalam pertumbuhannya pada kondisi biofisik, teknologi dan kondisi sosial ekonomi petani di suatu wilayah (Hendayana, 2003).

\section{Kemiskinan}

Pengertian kemiskinan menurut Sumodiningrat (1999) dapat diklasifikasikan ke dalam lima kelas yakni :

1. Kemiskinan Absolut, terjadi jika pendapatan penduduk tidak cukup memenuhi kebutuhan hidup minimum antara lain kebutuhan pangan, sandang, kesehatan, perumahan dan pendidikan yang diperlukan untuk hidup dan bekerja.

2. Kemiskinan Relatif, terjadi jika pendapatan penduduk di atas garis kemiskinan, namun relatif rendah bila dibandingkan dengan pendapatan masyarakat sekitarnya.

3. Kemiskinan Kultural, mengacu pada sikap seseorang atau masyarakat yang disebabkn oleh faktor budaya untuk tidak mau berusaha memperbaiki tingkat kehidupannya meskipun ada usaha dari pihak luar untuk membantunya.

4. Kemiskinan Kronis, disebabkan oleh kondisi sosial budaya yang mendorong sikap dan kebiasaan hidup masyarakat yang tidak produktif ditambah dengan keterbatasan sumber daya dan keterisolasian daerah dan tidak mendukungnya sumber daya alam serta rendhnya taraf pendidikan, kesehatan, keterbatasan lapangan kerja dan ketiakberdayaan masyarakat dalam mengikuti ekonomi pasar.

5. Kemiskinan Sementara, terjadi akibat perubahan siklus ekonomi dari kondisi normal ke krisis ekonomi, perubahan kondisi alam yag terkait dengan petani atau nelayan serta terjandinya bencana alam atau dampak dari kebijakan tertentu yang menyebabkan terjadinya penurunan tingkat kesejahteraan suatu masyarakat.

Menurut Andre (1996), kemiskinan itu bersifat multi dimensional. Artinya, karena kebutuhan manusia itu bermacam-macam, maka kemiskinan pun memiliki banyak aspek. Dilihat dari kebijakan umum, maka kemiskinan meliputi aspek primer yang berupa miskin akan aset, organisasi sosial politik, dan pengetahuan, serta ketrampilan dan aspek sekunder yang berupa miskin akan jaringan sosial, sumber-sumber keuangan dan informasi. Dimensi-dimensi kemiskinan tersebut termanifestasikan dalam bentuk kekurangan gizi, air, perumahan yang sehat, perawatan kesehatan yang kurang baik, dan tingkat pendidikan yang rendah. 


\section{METODE PENELITIAN}

\section{Data dan Sumber Data}

Penelitian ini dibatasi dengan menganalisis data sekunder deskriptif kuantitatif. Data sekunder merupakan sumber data penelitian yang diperoleh peneliti secara tidak langsung melalui media perantara atau diperoleh dan dicatat oleh pihak lain (Indriantoro, 1999). Penelitian deskriptif merupakan metode penelitian yang berusaha menggambarkan dan menginterpretasi objek sesuai dengan data yang sebenarnya. Penelitian kuantitatif adalah penelitian ilmiah yang sistematis terhadap bagian-bagian dan fenomena serta hubunganhubungannya. Sumber data berasal dari berbagai sumber antara lain, Bank Indonesia, Badan Pusat Statistik Nasional, jurnal-jurnal ilmiah dan literature-literatur lain yang berkaitan dengan topik penelitian ini. Selain itu, penulis juga melakukan studi literature untuk mendapatkan teori yang mendukung penelitian. Referensi studi kepustakaan diperoleh melalui jurnal-jurnal penelitian terdahulu.

\section{Tempat dan Waktu Penelitian}

Tempat penelitian ini adalah di Kabupaten Minahasa Utara dengan pengambilan data melalui Badan Pusat Statistik Sulawesi Utara untuk pengambilan data penelitian. Waktu penelitian adalah tahun 2010-2015.

\section{Metode Pengumpulan Data}

Teknik pengumpulan data yang digunakan adalah:

1. Library Research (Penelitian Kepustakaan)

Penelitian melalui beberapa buku bacaan, literatur atau keteranganketerangan ilmiah untuk memperoleh teori yang melandasi dalam menganalisa data yang diperoleh dari lokasi penelitian.

2. Internet Research

Penelitian melalui website untuk memperoleh teori dan data dalam penelitian ini.

\section{Metode Analisis}

\section{Analisis LQ (Location Quotient)}

Analisis LQ merupakan salah satu pendekatan tidak langsung yang digunakan untuk mengetahui apakah suatu sektor merupakan sektor basis/non-basis dan apakah suatu komoditas merupakan unggulan suatu daerah. Dengan kata lain, nilai LQ akan memberikan indikasi kemampuan suatu daerah dalam menghasilkan suatu komoditas, apakah mempunyai potensi untuk mensuplai daerah lain, mendatangkan dari daerah lain, atau dalam keadaan seimbang. Secara matematis, rumus LQ adalah sebagai berikut:

$$
\mathbf{L Q}=(\mathbf{p i} / \mathbf{p t}) / \mathbf{P i} / \mathbf{P t}
$$


Kerterangan:

LQ = Location Quotient

pi $\quad=$ Produksi/luas areal komoditas i pada tingkat kecamatan

pt $\quad=$ Produksi/luas areal total komoditas pada tingkat kecamatan

$\mathrm{Pi} \quad=$ Produksi/luas areal komoditas pada tingkat kabupaten

$\mathrm{Pt}=$ Produksi/luas areal total komoditas pada tingkat kabupaten

\section{Kriteria:}

LQ > 1 :sektor basis, artinya komoditas i di suatu wilayah memiliki keunggulan komparatif.

LQ $<1 \quad$ : sektor non-basis, artinya komoditas i di suatu wilayah tidak memiliki

keunggulan, produksinya hanya cukup untuk memenuhi kebutuhan wilayah sendiri.

\section{Analisis Shift Share}

Analisa ini terutama ditujukan untuk melihat kedudukan suatu daerah dalam sistem daerah yang lebih luas ditinjau dari suatu kegiatan ekonomi tertentu; begitu pula akan diperoleh suatu kesimpulan kegiatan-kegiatan ekonomi tertentu yang mempunyai perkembangan menonjol (potensi dan dominan ) dibandingkan dengan sektor kegiatan lain dalam suatu daerah tertentu.

Analisis shift-share dilaksanakan dengan menggunakan beberapa metode secara bertahap sesuai rangkaian sebagai berikut :

\section{Total Shift}

Metoda ini ditujukan untuk membandingkan indikator-indikator pertumbuhan daerah dengan gambaran-gambaran (terhadap daerah yang lebih luas).

ST $=E j t-(E t / E o)$ Ejo

Keterangan:

Ejt = besaran aktivitas ekonomi di daerah/volume aspek pertumbuhan di daerah $\mathrm{j}$ pada tahun terakhir

Ejo = besaran aktifitas ekonomi di daerah $\mathrm{j}$ pada tahun dasar

Et = basaran aktifitas ekonomi di daerah yang lebih luas pada tahun terakhir

Eo = besaran aktifitas ekonomi di daerah yang lebih luas pada tahun dasar

Dari hasil perhitungan, bila :

Nilai ST $(+)=$ upward total shift aktivitas ekonomi tersebut berkembang

Nilai ST $(-)=$ downward total shift aktivitas ekonomi tersebut berkembang lambat.

\section{Differential Shift}

Metoda ini didasarkan pada kenyataan bahwa jenis-jenis kegiatan ekonomi di suatu daerah mempunyai tingkat pertumbuhan yang lebih cepat dibandingkan dengan pertumbuhan kegiatan ekonomi tersebut di daerah yang lebih luas. 
Dimana :

\section{Sd = Eijt $-($ Eit $/$ Eio $)$ Eijo}

Sd $\quad=$ Differential shift

Eijt = besaran aktivitas ekonomi I di daerah $\mathrm{j}$ pada tahun terakhir

Eijo = besaran aktivitas ekonomi I di daerah $\mathrm{j}$ pada tahun dasar

Eit = besaran aktivitas ekonomi di daerah yang lebih luas pada tahun terakhir

Eio = besaran aktivitas ekonomi di daerah yang lebih luas pada tahun dasar Dari

hasil perhitungan, maka apabila :

Nilai Sd (+) = aktivitas ekonomi tersebut berkembang pesat. Selain itu juga memberikan indikasi bahwa daerah tersebut memiliki hubungan (akses) ke pasar dan tempat bahan baku yang relatif baik

Nilai Sd (-) = aktivitas ekonomi tersebut berkembang dengan lambat

\section{Propotional Shift}

Metoda ini didasarkan pada kenyataan bahwa ada pertumbuhan aktivitas ekonomi tertentu di suatu daerah yang berkembang lebih cepat/lambat dibandingkan dengan pertumbuhan ekonomi secara umum.

$$
\mathbf{S P}=\mathrm{ST}-\mathrm{SD}
$$

Dimana :

SP $\quad=$ Propotional Shift

ST $\quad=$ Total Shift

SD $\quad=$ Net Difrentiao Shift

Dari hasil perhitungan, bila :

Nilai SP $(+) \quad=$ daerah tersebut berspesialisasi dalam aktivitas ekonomi yang cepat pertumbuhannya

Nilai SP (-) = daerah tersebut berspesialisasi dalam aktivitas ekonomi yang lambat pertumbuhannya

\section{Share Analysis}

a) Penggunaan analisis share ini adalah untuk membantu mendefinisikan daerah dengan menghubungkan secara kuantitatif dan kualitatif terhadap total sistem daerah yang luas.

b) Memberikan karakteristik struktur ekonomi berbagai wilayah dalam ukuran relative.

c) Memperlihatkan berbagai aspek pertumbuhan baik sama maupun menyimpang terhadap karakteristik sistem daerah yang lebih luas.

d) Membantu memberikan karakteristik elemen-elemen yang stabil baik dalam struktur ekonomi daerah maupun struktur ekonomi sistem daerah yang lebih luas.

$$
H=E j o(E t / E o)-E j o
$$

Keterangan: 
Ejo = besaran aktivitas ekonomi di daerah $\mathrm{j}$ pada tahun dasar

Et = besaran aktivitas ekonomi di daerah $\mathrm{j}$ sistem daerah yang lebih luas pada tahun terakhir

Eo = besaran aktivitas ekonomi nasional atau sistem daerah yang lebih luas pada tahun dasar.

\section{Analisis Regresi Berganda}

Teknik analisis yang digunakan untuk menjawab permasalahan/ hipotesis dalam penelitian ini adalah menggunakan analisis regresi linier berganda. Analisis regresi linear berganda pada dasarnya adalah studi ketergantungan variable dependent (terikat) dengan satu atau lebih variabel independent (variable penjelas/bebas), dengan tujuan untuk mengestimasi dan/atau memprediksi rata-rata populasi atau nilai rata-rata variabel dependen berdasarkan nilai variabel independen yang diketahui (Gujarati,2003).

Adapun formula untuk metode Analisis Regresi Berganda adalah sebagai berikut:

$$
Y=\beta_{0} X+\beta_{1} X_{1}+\beta_{2} X_{2}+\beta_{3} X_{3}+e
$$

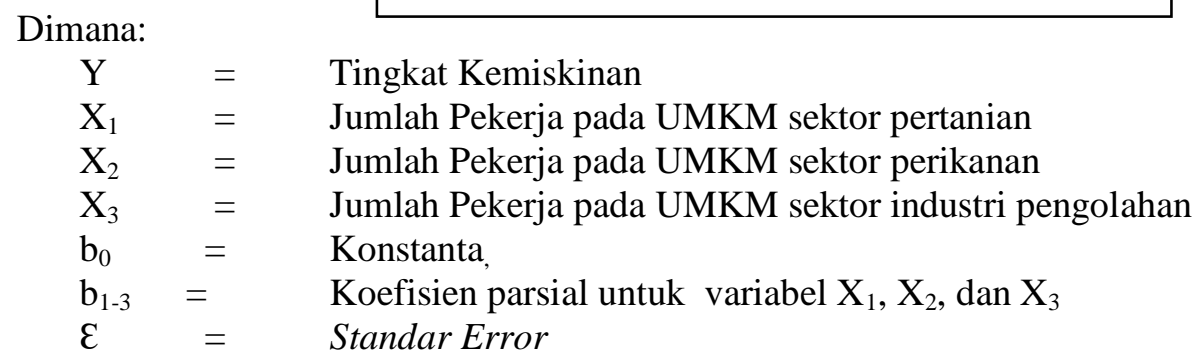

Dengan analisis regresi akan diketahui kekuatan dan arah hubungan antara variabel dependen yaitu kemiskinan rumahtangga dengan variabel independen : lama sekolah KK, umur KK, dan Ratio luas rumah per kapita. Teknik estimasi variabel dependen yang melandasi analisa regresi tersebut dinamakan Ordinary Least Square (OLS).

Koefisien Korelasi (R) digunakan untuk mengukur tingkat hubungan antara variabel bebas $(\mathrm{X})$ terhadap variabel $(\mathrm{Y})$. Besarnya koefisien determinasi adalah 0 sampai 1. Semakin mendekati 0 (nol) besarnya koefisien determinasi $\left(r^{2}\right)$ suatu persamaan regresi, semakin kecil hubungan variabel independen terhadap variabel dependen. Sebaliknya mendekati 1 (satu) besarnya koefisien determinasi $\left(\mathrm{r}^{2}\right)$ suatu persamaan regresi, semakin besar hubungan variabel independen terhadap variabel dependen.

\section{HASIL DAN PEMBAHSAN}

\section{Analisis sektor dan komoditi unggulan}

\section{Analisis location quotient (LQ)}

Dari hasil LQ di dapat bahwa di Kabupaten Minahasa Utara dari 17 sektor terdapat 7 sektor yang basis atau unggulan. Dari tahun 2010 sampai 2015 sektor Pertambangan dan Penggalian adalah sektor yang nilai LQ paling tinggi di Kabupaten Minahasa Utara dengan nilai LQ rata-rata sebesar 2.10. Kemudian diikuti oleh sektor Real Estate dengan nilai LQ ratarata sebesar 1.53. Selanjutnya sektor Pertanian, Kehutanan, dan Perikanan memiliki nilai ratarata LQ sebesar 1,34. Sektor industri pengolahan merupakan sektor basis dengan nilai LQ rata- 
rata sebesar 1.27, selanjutnya sektor pengadaan listrik dan gas memiliki nilai LQ rata-rata sebesar 1.12 kemudian sektor jasa pendidikan dengan nilai LQ rat-rata sebesar 1,11 dan yang terakhir sektor konstruksi memiliki nilai LQ rata-rata 1,06 Sektor-sektor ini merupakan sektor Basis atau unggulan artinya, sektor-sektor ini telah mampu memenuhi kebutuhan daerahnya sendiri.

Tabel 2

Hasil Perhitungan Location Quotient (LQ) Kabupaten Minahasa Utara Tahun 2010-2015

\begin{tabular}{|c|c|c|c|c|c|c|c|c|c|}
\hline No & Sektor Ekonomi & 2010 & 2011 & 2012 & 2013 & 2014 & 2015 & $\begin{array}{l}\text { Rata- } \\
\text { rata }\end{array}$ & Ket \\
\hline 1 & $\begin{array}{l}\text { Pertanian, Kehutanan, dan } \\
\text { Perikanan }\end{array}$ & 1,31 & 1,34 & 1,35 & 1,34 & 1,35 & 1,35 & 1,34 & Basis \\
\hline 2 & Pertambangan dan Penggalian & 2,07 & 2,07 & 2,08 & 2,13 & 2,12 & 2,12 & 2,10 & Basis \\
\hline 3 & Industri Pengolahan & 1,26 & 1,27 & 1,27 & 1,27 & 1,28 & 1,30 & 1,27 & Basis \\
\hline 4 & Pengadaan Listrik dan Gas & 1,16 & 1,17 & 1,15 & 1,15 & 1,08 & 1,03 & 1,12 & Basis \\
\hline 5 & $\begin{array}{l}\text { Pengadaan Air, Pengelolaan } \\
\text { Sampah, Limbah dan Daur Ulang }\end{array}$ & 0,59 & 0,59 & 0,59 & 0,59 & 0,58 & 0,58 & 0,58 & Non Basis \\
\hline 6 & Konstruksi & 1,05 & 1,04 & 1,07 & 1,05 & 1,08 & 1,10 & 1,06 & Basis \\
\hline 7 & $\begin{array}{l}\text { Perdagangan Besar dan Eceran; } \\
\text { Reparasi Mobil dan Sepeda Motor }\end{array}$ & 0,77 & 0,75 & 0,74 & 0,74 & 0,74 & 0,74 & 0,75 & Non Basis \\
\hline 8 & Transportasi dan Pergudangan & 0,50 & 0,51 & 0,51 & 0,51 & 0,50 & 0,50 & 0,50 & Non Basis \\
\hline 9 & $\begin{array}{l}\text { Penyediaan Akomodasi dan Makan } \\
\text { Minum }\end{array}$ & 0,48 & 0,49 & 0,48 & 0,48 & 0,48 & 0,47 & 0,48 & Non Basis \\
\hline 10 & Informasi dan Komunikasi & 0,47 & 0,45 & 0,45 & 0,45 & 0,45 & 0,45 & 0,45 & Non Basis \\
\hline 11 & Jasa Keuangan dan Asuransi & 0,23 & 0,23 & 0,22 & 0,21 & 0,21 & 0,21 & 0,22 & Non Basis \\
\hline 12 & Real Estate & 1,52 & 1,53 & 1,53 & 1,53 & 1,53 & 1,55 & 1,53 & Basis \\
\hline 13 & Jasa Perusahaan & 0,20 & 0,20 & 0,20 & 0,20 & 0,20 & 0,20 & 0,20 & Non Basis \\
\hline 14 & $\begin{array}{l}\text { Administrasi Pemerintahan, } \\
\text { Pertahanan dan Jaminan Sosial } \\
\text { Wajib }\end{array}$ & 0,53 & 0,55 & 0,54 & 0,57 & 0,57 & 0,56 & 0,55 & Non Basis \\
\hline 15 & Jasa Pendidikan & 1,08 & 1,10 & 1,10 & 1,12 & 1,12 & 1,12 & 1,11 & Basis \\
\hline 16 & Jasa Kesehatan dan Kegiatan Sosial & 0,73 & 0,72 & 0,71 & 0,71 & 0,70 & 0,69 & 0,71 & Non Basis \\
\hline 17 & Jasa lainnya & 0,40 & 0,40 & 0,40 & 0,40 & 0,39 & 0,39 & 0,40 & Non Basis \\
\hline
\end{tabular}

Secara umum dapat pula diartikan bahwa sektor-sektor basis tidak hanya mampu berproduksi untuk memenuhi kebutuhan daerahnya sendiri, tetapi juga mampu memasok untuk kebutuhan daerah lain. Sektor-sektor ini sangat berpotensi untuk di kembangkan dan bisa menjadi sumber daya untuk mendorong perekonomian Kabupaten Minahasa Utara Karena memiliki kekuatan dan prospek yang baik dimasa datang. 


\section{Analisis Shift Share (SS)}

\section{Tabel 3}

Perhitungan Analisis Shift Share di Kabupaten Minahasa Utara Tahun 2010-2015

\begin{tabular}{|c|c|c|c|c|c|}
\hline No & Sektor Ekonomi & $\begin{array}{l}\text { National } \\
\text { Share }\end{array}$ & $\begin{array}{l}\text { Propotional } \\
\text { Shift }\end{array}$ & $\begin{array}{l}\text { Diferential } \\
\text { Shift }\end{array}$ & Total Kinerja \\
\hline 1 & $\begin{array}{l}\text { Pertanian, Kehutanan, dan } \\
\text { Perikanan }\end{array}$ & $13.838 .275,62$ & $(6.088 .655,11)$ & $2.172 .933,55$ & $9.922 .554,07$ \\
\hline 2 & $\begin{array}{l}\text { Pertambangan dan } \\
\text { Penggalian }\end{array}$ & $4.831 .420,24$ & $588.689,94$ & $758.645,45$ & $6.178 .755,63$ \\
\hline 3 & Industri Pengolahan & $6.542 .144,42$ & $(1.269 .659,62)$ & $1.027 .269,29$ & $6.299 .754,09$ \\
\hline 4 & Pengadaan Listrik dan Gas & $51.969,32$ & $48.349,43$ & $8.162,41$ & $108.481,16$ \\
\hline 5 & $\begin{array}{l}\text { Pengadaan Air, } \\
\text { Pengelolaan Sampah, } \\
\text { Limbah dan Daur Ulang }\end{array}$ & $39.551,41$ & $(6.721,03)$ & $6.210,39$ & $39.040,77$ \\
\hline 6 & Konstruksi & $6.361 .297,97$ & $1.582 .419,61$ & $998.871,79$ & $8.942 .589,37$ \\
\hline 7 & $\begin{array}{l}\text { Perdagangan Besar dan } \\
\text { Eceran; Reparasi Mobil } \\
\text { dan Sepeda Motor }\end{array}$ & $4.405 .932,51$ & $968.709,66$ & $691.835,00$ & $6.066 .477,17$ \\
\hline 8 & $\begin{array}{l}\text { Transportasi dan } \\
\text { Pergudangan }\end{array}$ & $1.954 .158,05$ & $357.532,86$ & $306.848,33$ & $2.618 .539,24$ \\
\hline 9 & $\begin{array}{l}\text { Penyediaan Akomodasi dan } \\
\text { Makan Minum }\end{array}$ & $469.282,32$ & $146.920,86$ & $73.688,01$ & $689.891,19$ \\
\hline 10 & Informasi dan Komunikasi & $925.591,69$ & $323.523,66$ & $145.340,02$ & $1.394 .455,38$ \\
\hline 11 & Jasa Keuangan \& Asuransi & $375.247,33$ & $30.846,44$ & $58.923,59$ & $465.017,36$ \\
\hline 12 & Real Estate & $2.590 .276,78$ & $576.131,28$ & $406.733,26$ & $3.573 .141,32$ \\
\hline 13 & Jasa Perusahaan & $7.433,42$ & $2.193,37$ & $1.167,31$ & $10.794,09$ \\
\hline 14 & $\begin{array}{l}\text { Administrasi Pemerintahan, } \\
\text { Pertahanan dan Jaminan } \\
\text { Sosial Wajib }\end{array}$ & $1.842 .524,53$ & $101.502,70$ & $289.317,76$ & $2.233 .345,00$ \\
\hline 15 & Jasa Pendidikan & $1.324 .891,39$ & $(103.979,09)$ & $208.037,66$ & $1.428 .949,96$ \\
\hline 16 & $\begin{array}{l}\text { Jasa Kesehatan dan } \\
\text { Kegiatan Sosial }\end{array}$ & $1.242 .252,56$ & $239.125,48$ & $195.063,29$ & $1.676 .441,32$ \\
\hline 17 & Jasa lainnya & $291.204,80$ & $36.518,25$ & $45.725,66$ & $373.448,71$ \\
\hline \multicolumn{2}{|r|}{ PDRB } & 47.093.454,35 & $(2.466 .551,31)$ & 7.394.772,77 & $52.021 .675,82$ \\
\hline
\end{tabular}


berikut:

Perubahan relatif struktur ekonomi Kabupaten Minahasa Utara di sebabkan sebagai

1. Pertumbuhan ekonomi nasional (National growth effect), yang menunjukkan bagaimana pengaruh pertumbuhan ekonomi nasional terhadap perekonomian Kabupaten Minahasa Utara

2. Pergeseran Proporsional (proportional shift), yang menunjukkan perubahan relatif (naik/turun) kinerja suatu sektor di Kabupaten Minahasa Utara terhadap sektor yang sama Provinsi Sulawesi Utara. Pergeseran proporsional (proportional shift) di sebut juga pengaruh bauran industri.

3. Pergeseran Diferensial (diferential shift), yang menunjukkan tingkat kekompetitifan suatu sektor tertentu di Kabupaten Minahasa Utara di banding tingkat propinsi Sulawesi Utara. Jika nilai pergeseran diferensialnya positif, berarti sektor tersebut di Kabupaten Minahasa Utara lebih kompetitif di banding sektor yang sama di tingkat perekonomian propinsi. Pergeseran diferensial ini di sebut juga pengaruh keunggulan kompetitif.

Berdasarkan hasil perhitungan yang diperoleh pada Tabel 5.3 untuk kinerja perekonomian dapat dilihat bahwa :

a) Nilai National Shere Total sebesar 47.093.454,35 menunjukan bahwa pertumbuhan ekonomi Sulawesi utara kurun waktu 2010-2015 telah memberikan pengaruh yang positif terhadap kegiatan perekonomian Kabupaten Minahasa Utara dimana hal ini terlihat pada seluruh nilai sektor ekonomi Kabupaten Minahasa Utara yang positif dengan nilai output perekonomian sebesar Rp 47.093.454,350,000

b) Nilai proporsional (Proportional Shift) secara keseluruhan perekonomian di Kabupaten Minahasa Utara belum mengalami kemajuan karena dilihat dari hasil Proportional Shift mendapatkan hasil PDRB yaitu $(2.466 .551,31)$.

c) Nilai Differential Shift sebesar 7.394.772,77 menunjukan perkembangan perekonomian Kabupaten Minahasa Utara mempunyai daya saing yang tinggi atau cepat. Sektor yang mendapatkan hasil positif dalam Differential Shift berarti mempunyai daya saing yang tinggi dan keunggulan kompetitifnya tinggi.

d) Perekonomian Kabupaten Minahasa Utara mendapatkan hasil yang sangat positif terhadap nilai Total Kinerja selama kurun waktu 2010-2015 karena mengalami kenaikan nilai absolute serta keunggulan kinerja perekonomian daerah sebesar $52.021 .675,82$

\section{Analisis Sektor dan Komoditi Unggulan Dalam Mempercepat Penanggulangan Kemiskinan di Kabupaten Minahasa Utara}

Berdasarkan analisis sebelumnya diperoleh informasi bahwa yang menjadi sektor basis di Kabupaten Minahasa Utara adalah:

1. Sektor Pertanian, kehutanan dan perikanan;

2. Sektor pertambangan dan penggalian;

3. Sektor Industri pengolahan;

4. Sektor pengadaan listrik dan gas;

5. Sektor konstruksi;

6. Sektor Real Estate

7. Sektor Jasa Pendidikan.

Peran sektor ini akan lebih memberikan multiplier efek jika bisa memebantu pemerintah daerah dalam mempercepat penanggyulangan kemiskinan di Kabupaten Minahasa Utara. Analisis diperdalam dengan melihat tenaga kerja yang dipergunakan oleh sektor 
pertanian,kehutanan dan perikanan; sektor industri pengolahan; dan sektor konstruksi khususnya pada unit usaha mikro, kecil dan menengah.

Pengaruh sector dan komoditi unggulan dianalisis lebih jauh dengan model ekonometrika untuk mendapatkan informasi tentang pengaruh dari faktor yang diduga dominan berdasarkan analisa deskiptif sebelumnya dan sektor yang berpengaruh terbesar pada percepatan penanggulangan kemiskinan di Kabupaten Minahasa Utara. Analisis regresi berganda menjadi model yang diangkat peneliti dalam tulisan ini.

Model yang dibangun menunjukkan bahwa Tingkat Kemiskinan (P0) diduga dipengaruhi oleh jumlah tenaga kerja di sektor pertanian (X1); jumlah tenaga kerja di sector industri pengolahan (X2); dan jumlah tenaga kerja di sektor konstruksi (X3).

Model penelitian :

$\mathrm{PO}=\mathrm{a}+\mathrm{b}_{1} \mathrm{X}_{1}+\mathrm{b}_{2} \mathrm{X}_{2}+\mathrm{b}_{3} \mathrm{X}_{3}+\varepsilon$

atau $\mathrm{PO}=\mathrm{f}$ (tk.sektor pertanian, tk. Sektor industri pengolahan, tk sektor konstruksi)

Hasil penelitian menunjukkan bahwa

$\mathrm{PO}=0,0031-0,148 \mathrm{X}_{1}^{*}-0,193 \mathrm{X}_{2} *-0,0105 \mathrm{X}_{3} *+\varepsilon$

Ket : *) signifikan

Penelitian ini juga melakukan interview mendalam pada beberapa pengambil keputusan seperti Sekertaris Dinas Perindustrian dan Perdagangan Kabupaten Minahasa Utara, beberapa lurah di kelurahan yang ada, dan langsung pada UMKM sektor dan komoditi unggulan di Minahasa Utara.

Tampak bahwa tingkat percepatan penanggulangan kemiskinan secara signifikan dipengaruhi oleh jumlah tenaga kerja yang bekerja di UMKM sektor/komoditi unggulan. Dimana hubungan variabel bebas terhadap variabel terikat menunjukkan bahwa peningkatan pada jumlah tenaga kerja yang bekerja mendorong terjadinya penurunan tingkat kemiskinan di Kabupaten Minahasa Utara. Sektor yang menyerap tenaga kerja paling berpengaruh besar pada percepatan penanggulangan kemiskinan adalah sektor industri pengolahan dan diikuti jumlah penduduk yang bekerja di sector pertanian dan yang terakhir adalah jumlah tenaga kerja di sektor konstruksi.

Dilihat dari koefisien Determinasi menunjukkan bahwa ketiga variabel bebas berpengaruh signifikan pada variabel terikat secara terpisah (uji T) dan bersama-sama (uji F), Perubahan pada peningkatan atau penurunan variabel bebas mempengaruhi perubahan pada tingkat kemiskinan di Kabupaten Minahasa Utara adalah sebesar 52,56 persen dan sisanya di pengaruhi oleh jumlah pekerja yang bekerja di UMKM sektor lainnya. Hubungan variabel bebas dan variabel terikat bedasarkan koefisien korelasi adalah sebesar 72,5 persen. Hasil survey lapangan menunjukkan bahwa untuk komoditi kelapa produktivitas tenaga kerja pada industri kelapa paling tinggi terdapat pada PT Uniticon, dengan tingkat produktivitas 14,604.46\%, dengan jumlah produksi sebesar 7,200,000 ton dan jumlah tenaga kerja sebanyak 493 orang .

\section{Gambar 1 Produktivitas Komoditi Kelapa di Minahasa Utara}




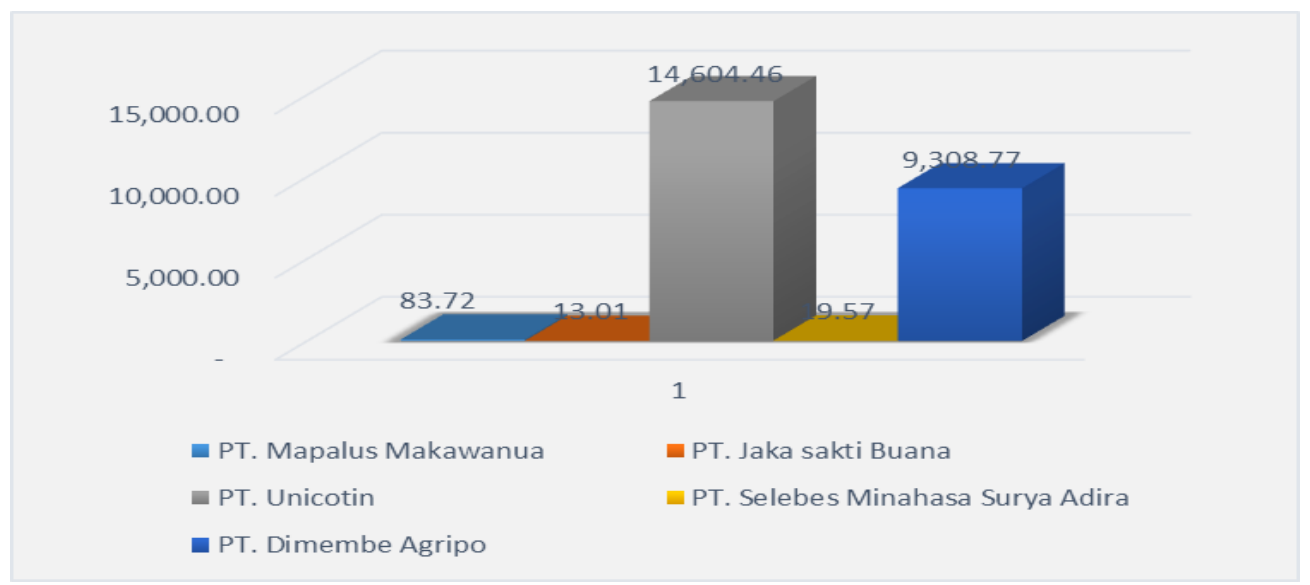

Sumber :data diolah, 2017

Jika di lihat dari survey produk yang dihasilkan melalui industry pengolahan ternyata yang paling besar produktivitasnya adalah mereka yang menghasilkan produk kimia dan bahan bangunan sebesar 207.759 juta rupiah/pekerja. Untuk produk pangan sebesar 74.230 juta rupiah/pekerja. Sedangkan produktivitas produk sandang dan kulit sebesar 35.690 juta rupiah/pekerja, produk logam dan elektronik sebesar 32.880 juta rupiah/produk dan yang terakhir produk kerajinan dan umum sebesar 8.772 juta rupiah/pekerja.

\section{Grafik 1 Produktivitas Industri Pengolahan Per Produk Kabupaten Minahasa Utara Tahun 2015}

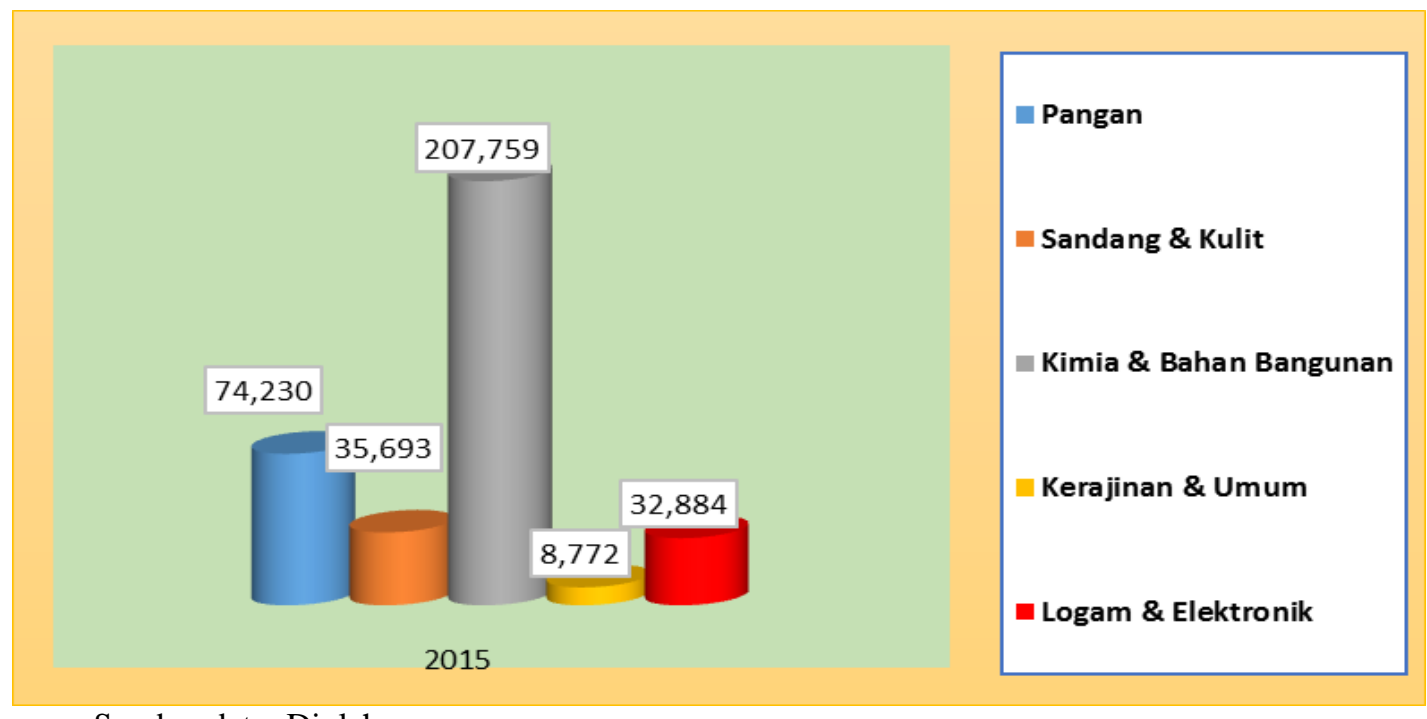

Sumber data: Diolah

Berdasarkan hasil survei, data dan informasi yang diperoleh dari Pemerintah Kabupaten Minahasa Utara, khususnya instansi/SKPD terkait yakni Bappeda/Bapelitbang, BKPMD, Dinas Perindag, Dinas Pertanian, Dinas Koperasi, Dinas Pariwisata serta pelaku/asosiasi pelaku usaha bahwa produk/komoditas/industri yang memiliki nilai ekonomi paling tinggi (unggulan) terdiri atas kelapa, pala, cengkih, jagung serta produk turunan dari sektor pariwisata. Produk - produk ini diproduksi dan menjadi produk unggulan di daerah ini karena keadaan alam yang sangat mendukung terhadap budidaya dan pelestarian produk tersebut. Selain itu juga produk - produk ini menjadi produk unggulan di daerah ini karena alasan - alasan seperti kelebihan dan keunikan 
kualitas produk seperti produk pala yang hanya cocok tumbuh di Minahasa Utara dan Kabupaten Kep.Sangihe, Brand Image produk dengan logo khusus TONSEA, pengembangan penelitian tanaman kelapa dan pala, pembentukan kelembagaan (koperasi petani) yang ditunjang dan dibiayai pemerintah daerah. Hal ini pun didukung dengan pelaksanaan berbagai program pelatihan sesuai dengan visi dan misi kepala daerah, lingkungan dan masyarahat daerah, terutama yang berkaitan erat berhubungan dengan pengembangan komoditi/produk dan home industry. Kekuatan penting lainnya yakni kegiatan usaha/produksi yang dilakukan oleh produsen/pelaku usaha/petani selain merupakan komitmen yang dilakukan secara konsisten, juga merupakan kegiatan usaha warisan/turun temurun. $\mathrm{Hal}$ - hal inilah yang menjadi kekuatan daerah dengan produk unggulannya.

Dari berbagai kekuatan yang dimiliki daerah terutama untuk produk unggulan, juga teridentifikasi beberapa kelemahan yang dapat melemahkan keberadaan produk - produk unggulan tersebut, yakni; petani masih memerlukan bimbingan untuk menghasilkan produk yang dapat dipasarkan di luar daerah bahkan mancanegara, pengolahan lahan tergantung pemilik lahan yang sebagian besar tidak berdomisili di Minahasa Utara, upah tenaga kerja yang relatif tinggi/mahal, keberadaan petani hanya sebagai petani penggarap, keterbatasan modal untuk pengembangan usaha, pengelolaan limbah yang belum maksimal / belum memenuhi standar, dan perlu proses pengembangan dalam memperoleh bahan baku sekalipun tersedia di wilayah tersebut.

Program pengembangan sarana dan prasarana produksi serta pelatihan - pelatihan yang merupakan terobosan baru dalam mengembangkan/meningkatkan kualitas produk unggulan tersebut merupakan peluang bagi produsen produk unggulan di daerah ini. Selain mendukung proses pemasaran produk unggulan seperti diikutsertakan dalam pameran yang berkaitan dengan pemasaran produk baik pada level kabupaten, provinsi, nasional bahkan internasional, pemerintah juga mendukung produsen dalam melakukan berbagai inovasi/modifikasi terhadap produk unggulan sehingga memenuhi tren produk seperti yang diinginkan oleh konsumen dan memberikan nilai tambah bagi produsen itu sendiri, sekalipun masih membutuhkan berbagai pengembangan. Peluang penting lainnya, yakni; pemerintah tetap dan terus konsisten dengan komitmen untuk mendukung keberlanjutan produk unggulan daerah ini.

Hasil survei ini juga mengidentifikasikan berbagai hambatan terhadap produksi dan pengembangan produk unggulan ini, diantaranya; Pengembangan infrastruktur jalan tol yang melintas di wilayah kabupaten Minahasa Utara telah mengurangi lahan budidaya tanaman kelapa dan pala, pengelolaan yang masih bersifat/dilakukan secara traditional, strategi pengembangan produk dan pemasaran yang dikembangkan oleh kompetitor yang juga berada di wilayah yang sama. Disamping menghadapi hambatan finansial berupa dana/modal usaha, hambatan lainnya juga adalah perubahan teknologi atau permintaan pasar yang begitu besar dan cepat berdasarkan standar tertentu turut mengancam proses pemasaran produk - produk unggulan di Kabupaten ini. Hal lain yang juga menjadi hambatan terutama dalam proses produksi yakni spesifikasi yang disyaratkan pada pekerjaan, produk dan pelayanan yang terus berubah secara dinamis serta bencana alam seperti kamarau yang berkepanjangan yang menyebabkan kekeringan dan berimbas terjadinya gagal panen.

Kelapa sebagai salah satu komoditi unggulan di Kabupaten Minahasa Utara memiliki berbagai produk turunan seperti tepung kelapa, sabut kelapa, arang tempurung, briket, VCO, sapu lidi dan kerajinan/ souvenir. Produk unggulan yang langsung diekspor adalah tepung kelapa dan briket. Saat ini para petani kelapa baru membentuk kelompok tani dan sudah terbentuk sentra-sentra seperti sentra batok kelapa, sentra lidi. Terdapat juga sentra kue basah, sentra gula aren, sentra tepung ubi kayu dan sentra pala Untuk asosiasi yang eksis adalah Asosiasi AMDK (air mineral dalam kemasan) yaitu aqua, ake dan asegar. Tahun 2017 sudah masuk usulan untuk sentra baso, abon dari kan dan nugget. Komoditi Pala banyak terdapat di 
Kaima dan Tumaluntung yang sudah mendapat bimbingan dan pelatihan dari kementrian menghasilkan berbagai produk seperti manisan pala, sirup pala, permen dan minyak pala.

Kendala utama petani atau pelaku usaha adalah masalah pemasaran dan modal. Saat ini pemasaran masih bersifat traditional dan di pasarkan di pasar swalayan. Di promosikan lewat kegiatan-kegiatan pameran di tingkat kabupaten, provinsi dan nasional. Pemerintah provinsi ikut memfasilitasi pemasaran berbagai produk UMKM dari berbagai kabupaten/kota pada kegiatan Pasar Lelang yang dilakukan 3 bulan sekali. Kendala lainnya adalah kemasan hasil home industry masih banyak yang belum memenuhi estándar. Termasuk VCO yang sudah dihasilkan dengan teknologi masih di label di Surabaya untuk di ekspor. Kelebihannya setiap kemasan produk yang sudah memenuhi standar terdapat logo tulisan 'TONSEA' yang menunjukkan produk tersebut adalah hasil dari Kabupaten Minahasa Utara.

Pengembangan komoditi unggulan kelapa dan pala di tahun 2017 menjadi prioritas, karena merupakan komoditi unggulan nasional. Pemerintah daerah akan mengembangkan 'Kelapa Genjah' untuk pembuatan gula nira dan kopra. Saat ini masih dalam taraf sosialisasi dengan penekanan bahwa kelapa yang ada saat ini khususnya yang tingginya maksimum 15 meter tetap akan digunakan oleh pemerintah. Petani hanya menyediakan lahan minimal $2 \mathrm{Ha}$ sedangkan bibit, pupuk dan mesin atau peralatannya akan disediakan pemerintah. Petani dapat memanfaatkan dana KUR untuk mengolah kelapa genjah yang bisa produksi dalam 5 (lima) tahun. Untuk mendapatkan pendapatan bulanan petani bisa menanam jagung di sela-sela kelapa genjah (jarak tanam $6 \times 16 \mathrm{~m}$ ), bisa dipanen setahun minimal 3 (tiga) kali. Bibit dan pupuk untuk menanam jagung juga disediakan oleh pemerintah, hanya petani membuat proposal permohonan jumlah bibit dan pupuk yang dibutuhkan. Pemerintah daerah akan memfasilitasi bagi petani yang akan mengambil dana KUR dengan subsidi bunga dalam 1 (satu) tahun. Program peremajaan kelapa besar-besaran menjadi target di tahun 2017 dan $100 \mathrm{Ha}$ untuk penanaman kelapa genjah dengan pengelolaan full mekanisasi.

Komoditi pala yang tersebar di 5 (lima) daerah terus diberdayakan dari budidaya sampai panen. Pemerintah sedang menyiapkan pengembangan 'Pala Organik' khusus di daerah lembean dan treman. Tujuannya untuk mendapatkan biji pala yang diekspor ke luar negeri bahkan bersertifikat internasional. Perawatannya yang harus diperhatikan karena harus higienis, tidak menggunakan pupuk kimia, masuk kebun pala tidak boleh merokok, pemetikan tidak boleh pakai tangan, buahnya tidak boleh jatuh, dan dikeringkan tidak boleh diatas tanah. Pemerintah akan memfasilitasi petani hanya dibutuhkan lahan yang akan menjadi Pilot Project. Mesin pengering pala akan diberikan oleh pemerintah. Petani akan di dampingi sampai membuahkan hasil. Saat ini sudah hampir 1000 kelompok tani bergerak di bidang pertanian yang telah mendapatkan berbagai pelatihan dan binaan yang dilakukan oleh SKPD terkait.

Sisi kelembagaan menunjukkan bahwa koperasi yang aktif saat ini ada 303 masih banyak yang sudah tidak produktif. Namun terdapat koperasi pertanian dan perikanan yang khusus untuk komoditi unggulan. Koperasi-koperasi tersebut seperti koperasi kerajian kelapa di desa Tetey dan Kema, Koperasi Pala di Winawerot dan Karegesan, Koperasi pertanian di Talawaan, Dimembe, Likupang dan Airmadidi, Koperasi perikanan di Likupang dan Kema, Koperasi Pupuk KUD Tamporok dan Koperasi Kopra. Berbagai fasilitas bantuan dari tingkat kementrian sampai kabupaten sudah dapat diakses oleh koperasi komoditi unggulan baik dalam bantuan modal UMKM tanpa jaminan dan bantuan peralatan pertanian. Koperasi juga memfasilitasi pemasaran dan bertindak sebagai pengumpul untuk komoditi ungulan.

\section{PENUTUP}




\section{Kesimpulan}

1. Sektor Basis di kabupaten Minahasa Utara adalah Sektor pertanian, kehutanan dan perikanan; Sektor pertambangan dan penggalian; Sektor industri pengolahan; Sektor pengadaan listrik dan gas; Sektor konstruksi; Sektor Real Estate dan Sektor Jasa Pendidikan.

2. Pertumbuhan ekonomi di Provinsi Sulawesi Utara memberikan pengaruh positif terhadap perekonomian di Kabupaten Minahasa Utara.

3. Perekonomian Kabupaten Minahasa Utara mengalami kemajuan dan mulai memiliki daya saing.

4. Sektor yang memberi pengaruh terbesar dalam percepatan penanggulangan kemiskinan di Kabupaten Minahasa Utara adalah sector industry pengolahan diikuti sector pertanian dan sektor konstruksi.

\section{Saran}

Dalam pengembangan usaha keberadaan produk yang dihasilkan terutama kualitas dan kemasan perlu terus dikembangkan sampai berstandar nasional. Pengelolaan limbah yang lebih banyak masih tradisional untuk industri mikro dan kecil. Tenaga kerja dengan keterbatasan pendidikan dan ketrampilan yang dimilki membuat pentingnya peran pemerintah untuk memberikan pendidikan non formal (ketrampilan) yang akan meningkatkan produktivitas mereka.

\section{DAFTAR PUSTAKA}

Arsyad,Azhar. 2005. Media Pemblajaran. Jakarta: Raja Grafindo Persada.

Adisasmita, H. R. 2005. Dasar-dasar Ekonomi Wilayah. Penerbit Graha Ilmu, Yogyakarta.

Anwar, A. dan E. Rustiadi. 2000. Perspektif Pembangunan Tata Ruang (Spatial) Wilayah

Pedesaan dalam Rangka Pembangunan Regional. Program Studi Ilmu Perencanaan Wilayah dan Pedesaan, IPB, Bogor.

Arsyad, L., 2005. Pengantar Perencanaan Pembangunan Ekonomi Daerah. Penerbit BPFE, Yogyakarta.

Alfian. (1980). Kemiskinan Struktural: Suatu Bunga Rampai. YIIS dan HIPIS, Jakarta.

Andre \& Bayo. (1996). Kemiskinan dan Strategi memerangi Kemiskinan. Penerbit Liberti, Yogyakarta.

Blakey, Edward J. dan Ted K. Bradshaw. 2002. Planning Local Economic Development Theory and Practice. Sage Publications, London.

Budiharsono S. 2001. Teknik Analisis Pembangunan Wilayah Pesisir dan Lautan. Penerbit Pradnya Paramita, Jakarta.

Dartanto,Nurkholis,dkk. (2008). The Determinant of Poverty Dynamics and The Role of Goverment Assistances on Canging Poverty Status in Indonesia : Empirical Evidence of Panel Data.

Dornbusch, Fischer \& Startz. (2004). Macroeconomics, ninth edition, Mc.Graw Hill, Int. Edition.

Gujarati, Damodar. (1999). Essential of Econometrics. second edition, McGraw-Hill Int.edition,Economies series.

Gujarati D.N \& Porter D.C. (2009). Basic Econometrics. fifth edition, Mc. Graw Hill Int. edition, New York. 
Hendayana, R. 2003. Aplikasi Metode Location Quotient (LQ) dalam Penentuan Komoditas Unggulan Nasional. Informatika Pertanian $12: 1-21$.

Holmes R,dkk, (2010), The Role of Social Protection in Tackling Food in Security and Undernutrition in Indonesia, SMERU Research Institute.

Jhingan, M.L, (1994), Ekonomi Pembangunan dan Perencanaan, PT. Raja Grafindo Persada, Jakarta.

Lajovic, Dragan. 2010. Regional Development in Montenegro - Entrepreneurial Aspect. Montenegrin Journal of Economics, Vol. 6 No. 12, pp. 107-112.

Nafziger, E. W. 2006. Economic Development. Cambridge University Press.

Partoatmodjo, Sadji. (2004). Masalah Kemiskinan dan Kompleksitas Penanggulangannya. Jurnal ALNI Indonesia, Jakarta.

Rostow, W. W. 1959. The Stages of Economic Growth. The Economic History Review. New Series, Vol. 12, No.1, p. 1-16.

Rustiadi, E., S. Saefulhakim, dan R. R. Panuju. 2011. Perencanaan dan Pengembangan Wilayah. Yayasan Pustaka Obor Indonesia, Jakarta.

Todaro, Michael P. and Smith, Stephen C. 2011. Economic Development. Eleventh Edition. United States: Addison Wesley. 